NBER WORKING PAPER SERIES

\title{
WHY THE APPLE DOESN'T FALL FAR: UNDERSTANDING THE INTERGENERATIONAL TRANSMISSION OF HUMAN CAPITAL
}

\author{
Sandra E. Black \\ Paul J. Devereux \\ Kjell G. Salvanes \\ Working Paper 10066 \\ http://www.nber.org/papers/w10066
NATIONAL BUREAU OF ECONOMIC RESEARCH
1050 Massachusetts Avenue
Cambridge, MA 02138
October 2003

The authors would like to thank Marina Bassi for helpful research assistance. We also thank Maia Guell, Oskar Nordstrøm Skans, and participants at ESSLE, SoLE, ITAM, the CEPR Uppsala Workshop, and at UCL for helpful suggestions. The views expressed herein are those of the authors and not necessarily those of the National Bureau of Economic Research.

(C2003 by Sandra E. Black, Paul J. Devereux, and Kjell G. Salvanes. All rights reserved. Short sections of text, not to exceed two paragraphs, may be quoted without explicit permission provided that full credit, including (C) notice, is given to the source. 
Why the Apple Doesn't Fall Far: Understanding Intergeneratioal Transmission of Human Capital Sandra E. Black, Paul J. Devereux, and Kjell G. Salvanes

NBER Working Paper No. 10066

October 2003

JEL No. I21, J13, J24

\section{$\underline{\text { ABSTRACT }}$}

Parents with higher education levels have children with higher education levels. However, is this because parental education actually changes the outcomes of children, suggesting an important spillover of education policies, or is it merely that more able individuals who have higher education also have more able children? This paper proposes to answer this question by using a unique dataset from Norway. Using the reform of the education system that was implemented in different municipalities at different times in the 1960s as an instrument for parental education, we find little evidence of a causal relationship between parents' education and children's education, despite significant OLS relationships. We find 2SLS estimates that are consistently lower than the OLS estimates with the only statistically significant effect being a positive relationship between mother's education and son's education. These findings suggest that the high correlations between parents'and children's education are due primarily to family characteristics and inherited ability and not education spillovers.

Sandra E. Black

Department of Economics

UCLA

9373 Bunche Hall

Los Angeles, CA 90095-1477

and NBER

sblack@econ.ucla.edu
Paul J. Devereux

Dept of Economics

UCLA

8283 Bunche Hall

Los Angeles, CA 90095

devereux@econ.ucla.edu
Kjell G. Salvanes

Department of Economics

Norwegian School of

Economics

and Business Administration

Helleveien 30, N-5045 Bergen

Norway

kjell.salvanes@nhh.no 


\section{Introduction}

Parents with higher education levels have children with higher education levels. But why? There are a number of possible explanations. One is a pure selection story; the type of parent who has more education, earns higher salaries, etc, has the type of child who will do so as well, regardless. Another story is one of causation; attaining more education makes you a different type of parent, and thus leads to your children having higher educational outcomes.

Distinguishing between these scenarios is important from a policy perspective. One of the key roles of publicly provided education in our society is to increase equality of opportunity, and many policies have been implemented to further that goal in recent years. ${ }^{1}$ Proponents of this type of education policy often cite as one of the benefits the spillover effects on to later generations; having more educated citizens will have longer run effects by improving the outcomes of their children. While many argue that this is the case, there is little causal evidence to suggest it is true; the research to date has been limited in its ability to distinguish between selection and causation.

This paper proposes to provide evidence on the causal link between parents' and children's education by using a unique dataset from Norway. During the 1960s, there was a drastic change in the compulsory schooling laws affecting primary and middle schools. Pre-reform, the Norwegian education system required children to attend school through the seventh grade; after the reform, this was extended to the ninth grade, adding two years of required schooling. Additionally, implementation of the reform occurred in different municipalities at different times, starting in 1960 and continuing through 1972, allowing for regional as well as time series variation. Evidence in the literature suggests 
that these reforms had a large and significant impact on educational attainment which, in turn, led to a significant increase in earnings. ${ }^{2}$ As a result, the reform provides variation in parental education that is exogenous to parental ability and enables us to determine the impact of increasing parental education on children's schooling decisions. Although the instrument only allows us to determine the impact of increasing parental education from seven to nine years, this may be an important starting point for identifying the intergenerational transmission of education.

Using this reform as an instrument for parental education, we find little evidence of a causal relationship between father's education and children's education, despite significant and large OLS relationships. We find a small but significant causal relationship between mother's education and her son's education but no causal relationship between mother's and daughter's educations. This suggests that high correlations between parental and children's education are due primarily to selection and not causation.

The paper unfolds as follows: Sections 2 and 3 will discuss relevant literature and describe the Norwegian Education reform. Sections 4 and 5 describe our empirical strategy and data. Section 6 discusses the effect of the Norwegian education reform on educational attainment, and Section 7 presents our results, providing first separate estimates of the effects of mothers' and fathers' education and then the results when both are included at the same time. Section 8 presents some specification checks, including checks for sample selection problems due to the age of our sample, selection into

1 For example, the "No Child Left Behind" program supported by President George W. Bush. 2 See Aakvik, Salavanes, and Vaage, 2003. Results on the impact of similar reforms on educational attendance also exists for Sweden, see Meghir and Palme (2003) and for England and Ireland, see Harmon and Walker (1995) and Oreopulos (2003). 
parenthood, and sibling fixed effects. Finally, Section 9 attempts to disentangle some possible explanations for the positive causal relationship we observe between education of mothers and sons, first looking at marital choices and then considering whether quality/quantity tradeoffs made by more educated women can explain the result. Section 10 then concludes.

\section{Background Information}

There is an extensive literature on the intergenerational transmission of income that focuses on the correlation of parental and children's permanent income. ${ }^{3}$ In work comparing Scandinavian countries with the United States, the evidence suggests that the more compressed is the income distribution, the smaller the correlation between parental and child outcomes. Bjorklund and Jantti (1997) compare intergenerational mobility in the U.S. and Sweden and find some evidence that intergenerational mobility is higher in Sweden. Bjorklund et al. (2002) extend this to include a comparison of intergenerational mobility in the U.S. to Norway, Denmark, Sweden and Finland and find support for greater income mobility in all the Scandinavian countries than in the US. Bratberg, Nilsen, and Vaage (2002) also explore the relationship between income inequality and mobility, focusing specifically on Norway, and argue that, over time, the compression of the earnings structure in Norway has increased intergenerational earnings mobility.

However, few studies focus on intergenerational mobility in education. Results from the US and UK suggest intergenerational education elasticities between 0.20 and 0.45 (Dearden et al., 1997; Mulligan, 1999). Using brother correlations in adult

\footnotetext{
${ }^{3}$ For a review of this literature, see Solon (1999).
} 
educational attainment as an overall measure of family and neighborhood effects, Raaum, Salvanes and Sorensen (2001) find results for Norway that are similar to those Solon (1999) reports for the US. None of these studies, however, attempts to distinguish a causal relationship.

In recent work, there has been some effort to distinguish causation from mere correlation in ability across generations. Three broad approaches have been used: identical twins, adoptees, and instrumental variables. Behrman and Rosenzweig (2002) use data on pairs of identical twin parents to "difference out" any correlation attributable to genetics. Simple OLS estimates, even controlling for father's schooling and father's log earnings, suggest a positive and significant relationship between mother's and children's schooling (with a coefficient of 0.13 on mother's schooling and coefficient of 0.33 on father's schooling, both significant). However, once one looks within female monozygotic twin pairs, thereby differencing out any genetic factors that influence children's schooling, the coefficient on mother's schooling turns negative and almost significant. The analogous fixed effects exercise using male monozygotic twin pairs gives coefficients for father's education that are about the same size as the OLS estimates. Recent work by Antonovics and Goldberger (2003), however, calls into question these results and suggests that the findings are quite sensitive to the coding of the data. Also, it may be unrealistic to assume that twins differ in terms of education but not in terms of any other characteristic or experience that may influence the education of their offspring (see Griliches, 1979 and Bound and Solon, 1999 for demonstrations that biases using sibling and twin fixed effects may be as big or bigger than OLS biases).

Plug (2002) uses data on adopted children to investigate the causal relationship 
between parental education and child education. If children are randomly placed with adoptive parents, the relationship between parental education and child education cannot simply reflect genetic factors. Plug finds a positive effect of father's education on child education but no significant effect for mothers. There are a number of limitations of this approach: sample sizes are tiny, children are not randomly placed with adoptive parents, and the correlation between parents' education and child education could be picking up the effects of any unobserved parental characteristic (patience, ability) that influences child outcomes. ${ }^{4}$

Closest to our paper is work by Chevalier (2003), who uses a change in the compulsory schooling law in Britain in 1957 to identify the effect of parental education on their offspring's education. He finds a large positive effect of mother's education on her child's education but no significant effect of paternal education. However, this paper suffers from the fact that the legislation was implemented nationwide; as a result, there is no cross-sectional variation in the British compulsory schooling law. Chevalier uses cohorts of parents born between 1948 and 1967 and instruments parental education with a dummy for whether they were affected by the law change, a linear trend reflecting year of birth, and the interaction of year of birth with the law dummy. Thus, he assumes away the presence of cohort effects in the second stage and the identifying variation in parental education arises both from secular trends in education and the once-off change in the law. ${ }^{5}$ Second, the sample only includes children who are still living at home with their

4 Sacerdote (2002) also uses adoptees to distinguish the effect of family background from genetic factors on children's outcomes; however, the focus of his paper is primarily the general impact of family socioeconomic status as opposed to the causal impact of parent's education.

5 This may be a particular problem in this context as less-educated individuals are more likely to have children while young and so in a sample of individuals with children of a certain age, older individuals are likely to have more education. Thus, one would like to control for unrestricted age effects for parents. 
parents and hence loses observations in a non-random fashion. ${ }^{6}$

\section{The Norwegian Primary School Reform}

In 1959, the Norwegian Parliament legislated a mandatory school reform. The reform was characterized by three broad goals, as stated explicitly in several government documents: 1) to increase the minimum level of education in society by extending the number of compulsory years of education from 7 to 9 years, 2) to smooth the transition to higher education, and 3) to enhance equality of opportunities both along socio-economic and geographical dimensions. Prior to the reform, children started school at the age of seven and finished compulsory education after seven years, i.e. at the age of fourteen. After the initial 7 years, there were two tracks: the General Education System for the higher ability students (which had a 3 year and a 5 year option) and the less selective Middle School which involved between 1 and 3 years of vocational training. In the new system, the starting age was still seven years old, but the time spent in compulsory education was now nine years. After the nine years of compulsory schooling, the student could either enroll in high school (which was made more accessible after the reform) or vocational training. ${ }^{7}$ In addition, the reform standardized the curriculum and increased access to schools, since 9 years of mandatory school was eventually made available in all municipalities and enrollment in high school was less competitive.

The parliament mandated that all municipalities (the lowest level of local

\footnotetext{
6 In related work, Currie and Moretti (forthcoming) find a positive effect of mothers' educational attainment on children's health outcomes in the U.S. using instrumental variables and fixed effects approaches.

${ }^{7}$ The Norwegian school system has been slightly changed recently by the so-called "Reform97". Children now start at the age of six and the time spent in compulsory education is ten years, of which seven are at primary school and three are at middle school.
} 
administration) must have implemented the reform by 1973; as a result, although it was started in 1960, implementation was not completed until 1972. ${ }^{8}$ This suggests that, for more than a decade, Norwegian schools were divided into two separate systems; which system you were in depended on the year you were born and the municipality in which you lived. The first cohort that could have been involved in the reform was the one born in 1947. They started school in 1954, and (i) either finished the pre-reform compulsory school in 1961, or (ii) went to primary school from 1954 to 1960, followed by the postreform middle school from 1960 to 1963 . The last cohort who could have gone through the old system was born in 1958. This cohort started school in 1965 and finished compulsory school in $1972 .{ }^{9}$

To receive funds from the government to implement the reform, municipalities had to present a plan to a committee under the Ministry of Education. Once approved, the costs of teachers and buildings would be provided by the national government. While the criteria determining selection by the committee are somewhat unclear, the committee did want to ensure that implementation was representative of the country, conditional on having an acceptable plan. (Telhaug, 1969, Mediås, 2000). Figure 1 presents the spread of the reform over time, focusing on the number of municipalities implementing the reform per year.

While it is not necessary for our estimation strategy, it would be useful if the timing of the implementation of the reform across municipalities were uncorrelated with

\footnotetext{
${ }^{8}$ The reform had already started on a small and explorative basis in the late $1950 \mathrm{~s}$, but applied to a negligible number of students because only a few small municipalities, each with a small number of schools, were involved. See Lie (1974), Telhaug (1969), and Lindbekk (1992), for descriptions of the reform.

${ }^{9}$ Similar school reforms were undertaken in many other European countries in the same period, notably Sweden, the United Kingdom and, to some extent, France and Germany (Leschinsky and Mayer, 1990).
} 
general educational levels. One might worry that poorer municipalities would be among the first to implement the reform, given the substantial state subsidies, while wealthier municipalities would move much slower. However, work examining the determinants of the timing of implementation finds no relationship between municipality characteristics such as average earnings, taxable income, and educational levels, and the timing of implementation. (See Lie 1973, 1974.) Municipalities that are located geographically near municipalities that already implemented the reform were themselves more likely to implement the reform; numerous interviews revealed that this was likely due to a particularly effective county administrator. As a result, the research supports a complex adoption process without finding support for a single important factor to explain the implementation process. To examine this ourselves, Figures 2, 3, and 4 examine the implementation of the reform by the average income, parental education, and size of the municipalities; these figures suggest that there is little relationship between these factors and the timing of the implementation of the reform.

As a more rigorous test, in Appendix Table 1 we regress the year of implementation on different background variables based on municipality averages, including parental income, the level of education, average age, and the size of the municipality, as well as county dummies (there are 20 counties in Norway). Consistent with the existing literature, there appears to be no systematic relationship between the timing of implementation and parent average earnings, education levels, average age, urban/rural status, industry or labor force composition, municipality unemployment rates in 1960, and the share of individuals who were members of the Labor party (the most pro-reform and dominant political party). 


\section{Identification Strategy}

To identify the causal effects of parents' education on children's education, it is useful to have variation in parents' education that is exogenous to parental ability and other factors that are correlated with both parents' and child's educational choice. Our source of exogenous variation is the education reform in Norway that increased the number of years of compulsory schooling from 7 to 9 years and was implemented primarily over a 12 year period from 1960 to 1971 in different municipalities at different times. Thus, there is both time-series and cross-sectional variation in the number of years of compulsory schooling required of individuals during this period. We then observe the children of this generation in 2000 .

Our empirical model is summarized by the following two equations:

$$
\begin{aligned}
& E D=\beta_{0}+\beta_{1} E D^{p}+\beta_{2} A G E+\beta_{3} F E M A L E+\beta_{4} A G E^{p}+\beta_{5} M_{U N I C I P A L I T Y}{ }^{P}+\varepsilon \\
& E D^{P}=\alpha_{0}+\alpha_{1} R_{E F O R M^{p}}+\alpha_{2} A G E+\alpha_{3} F_{E M A L E}+\alpha_{4} A G E^{p}+\alpha_{5} M U N I C I P A L I T Y^{P}+v(2)
\end{aligned}
$$

In equations (1) and (2), ED is the number of years of education obtained by the child, AGE refers to a full set of years of age indicators, MUNICIPALITY refers to a full set of municipality indicators, and REFORM equals 1 if the individual was affected by the education reform, and 0 otherwise. In all cases, the superscript $\mathrm{p}$ denotes parent, so that, for example, $\mathrm{AGE}^{\mathrm{p}}$ refers to a full set of indicator variables for the age of the parent. We estimate the model using Two Stage Least Squares (2SLS) so that equation (2) is the first stage and $R E F O R M^{p}$ serves as an instrumental variable for $E D^{P}$.

There are a few points to note about equations (1) and (2): First, both equations contain fixed age effects and municipality effects for parents. The age effects are 
necessary to allow for secular changes in educational attainment over time that may be completely unrelated to the reform. For instance, at this time there was a trend in Norway, as well as in other countries, of increasing educational attainment. The municipality effects allow for the fact that variation in the timing of the reform across municipalities may not have been exogenous to parents' educational choice. ${ }^{10}$ Even if the reform was implemented first in areas with certain unobserved characteristics, consistent estimation is still achieved so long as (a) these characteristics are fixed over time during the 12-year period or (b) implementation of the reform is not correlated with changes in these characteristics or (c) these characteristics are not related to the schooling of the children of this generation. $^{11}$

Second, we have included age indicators for the children to allow for the fact that not all children in our sample have finished schooling by 2000 . Third, we do not include any further child characteristics such as their area of residence as these are potentially endogenous to their years of schooling. For example, suppose the reform causes a woman to receive more education and this causes her to move to a city where educational costs are low and, hence, her children have high education. We consider this a causal effect of parental education on child education, even though it has arisen partly through the effect of parental education on the residence of the child.

\section{Data}

10 In section 3 we argued that the available evidence suggests no systematic patterns in the timing of reform implementation across municipalities. However, for example, early adopters may differ from late adopters of the reform if they value schooling more because the industrial composition in the municipality implies greater demand for skilled workers. These types of possibilities are controlled for by municipality fixed effects.

${ }^{11}$ In our estimation, we have also tried allowing for municipality-specific time trends as well as county by year fixed effects. Our results were insensitive to the inclusion of these extra variables. 
Based on different administrative registers and census data from Statistics Norway, a comprehensive data set has been compiled of the entire population in Norway, including information on family background, age, marital status, country of birth, educational history, neighborhood information, and employment information. ${ }^{12}$ The initial database is linked administrative data which covers the entire population of Norwegians aged 16-74. These administrative data provide information about educational attainment, labor market status and a set of demographic variables (age, gender). To this, we match extracts from the censuses in 1960, 1970 and 1980.

To determine whether parents were affected by the reform, we need to link each parent to the municipality in which they grew up. We do this by matching the administrative data to the 1960 census. From the 1960 census, we know the municipality in which the parent's mother lived in $1960 .{ }^{13}$ In 1960 , the parents we are using in the estimation are aged between 2 and 13. One concern is that there may be selective migration into or out of municipalities that implement the reform early. ${ }^{14}$ However, since the reform implementation did not occur before 1960, this could only be a problem for us to the extent that families anticipated where the reform would be implemented first and made mobility decisions prior to the 1960 census. Any reform-induced mobility subsequent to 1960 may affect the precision of our 2SLS estimates but not their consistency.

The measure of educational attainment is taken from a separate data source

\footnotetext{
12 See Møen, Salvanes and Sørensen (2003) for a description of the data set.

${ }^{13}$ Since very few children live with their father in the cases where parents are not living together, we should only have minimal misclassification by applying this rule.

${ }^{14}$ Evidence from Meghir and Palme (2003) on Sweden and Telhaug (1969) on Norway suggest that reforminduced migration was not a significant consideration.
} 
maintained by Statistics Norway; educational attainment is reported by the educational establishment directly to Statistics Norway, thereby minimizing any measurement error due to misreporting. This register provides detailed information on educational attainment. The educational register started in 1970; for parents who completed their education before then we use information from the 1970 Census. Thus the register data are used for all but the earliest cohorts of parents who did not have any education after 1970. Census data are self reported (4 digit codes of types of education were reported) and the information is considered to be very accurate; there are no spikes or changes in the education data from the early to the later cohorts.

Our primary data source on the timing of the reform in individual municipalities is the volume by Ness (1971). To verify the dates provided by Ness, we examined the data to determine whether or not there appears to be a clear break in the fraction of students with less than 9 years of education. In the rare instance when the data did not seem consistent with the timing stated in Ness, we checked these individual municipalities by contacting local sources. ${ }^{15}$ We are able to successfully calculate reform indicators for 545 out of the 728 municipalities in existence in 1960. If the reform took more than one year to implement in a particular municipality or we were not able to verify the information given in Ness (1971), we could not assign a reform indicator to that municipality. However, we have reform information for a large majority of individuals in the relevant cohorts.

We include cohorts of parents born between 1947 and 1958 in our sample. The sample of children includes all individuals in 2000 who are aged $20-35$. Note that a

15 Between 1960 and 1970, a number of municipalities merged. In our analysis, we use the 1960 municipality as the unit of observation. In cases where the data were available at the 1970 municipality 
great advantage of our data set over others in the literature is that we can link adult children in 2000 to characteristics of their parents, even in cases where the children do not live with their parents. Table 1 provides summary statistics for the individuals in our sample. $^{16}$

\section{The Effects of the Reform on Educational Attainment}

There is a significant literature examining the impact of compulsory schooling laws on educational attainment. ${ }^{17}$ In Norway, the legislation mandated a full two year change in schooling for individuals at the bottom of the educational distribution. Table 2 demonstrates the significance of this legislation. It shows the distribution of education averaged over the 2 years prior to the reform and the two years immediately after the reform (including the year the reform was implemented).

It is clear from this table that the primary effect of the reform was to reduce the proportion of people with fewer than 9 years of education to almost zero. In the 2 years prior to the change in the compulsory schooling laws, $12 \%$ of individuals completed fewer than 9 years of schooling. After the legislative change, we see that less than $3 \%$ of the population has fewer than 9 years of schooling, with a new spike at 9 years. ${ }^{18}$

In addition to changing the educational structure at the bottom end of the distribution, the reform eliminated much of the tracking of students done prior to the

level, individual municipalities were contacted to determine the appropriate coding. 16 Note that it sometimes occurs that one parent is in our sample while the other is not because only one of them is born during the 1947-1958 period.

17 For work on the U.S., see, for example, Acemoglu and Angrist (1999).

18 The presence of some individuals with fewer than 9 years of schooling when the reform is in place reflects the fact that compliance with the law was not $100 \%$ and some individuals dropped out before completing compulsory schooling. It may also reflect the fact that, in some municipalities, the reform was implemented over several years and also possibly some error in the dating of reform implementation. These factors will tend to reduce the precision of our estimates without affecting consistency. 
reform. As a result, the 3 versus 5 year General Education System was replaced by a single high school system with more generous admission standards and availability. As a result, the educational distribution appears to have a "hole" at 10 years of education after the reform (See Table 2); individuals who would have done the 3 year high school track before the reform would now have increased access to high school after 9 years of compulsory schooling and therefore ultimately achieve 10,11 or 12 years of schooling. This is consistent with the fact that the proportion of individuals with 10-12 years of education is similar before and after the reform.

\section{Restricting the Sample}

Because the primary impact of the reform is at the bottom of the educational distribution, we conduct much of our analysis on the sample of mothers/fathers who have 9 or fewer years of education. The additional assumptions we make in doing this are 1) that individuals who get 9 years of education after the reform would have received 9 years or less of education if the reform had not been in effect, and 2) that individuals who got 9 years or less of education before the reform would have received 9 years of education if the reform had been in effect. ${ }^{19}$ These are not testable but we describe below features of the data that suggest that our assumptions are not unreasonable.

First, consider Table 2. In this table, we see that the proportion of individuals with 9 years or less of education stays constant when we compare two years before to two years after the reform. This suggests that there may be no significant spillover effects of the reform; those who obtained 9 or fewer years of education before the reform would

19 This second assumption rules out spillover effects of the reform of the sort that some signaling models imply. 
have continued to do so after the reform.

Additionally, we have examined the family background characteristics of the individuals (parents) with 9 or fewer years of education in the years before and after the reform to check and see if the composition of our sample appears to have changed. If, for example, there were positive spillover effects of the reform, we might expect to see the post-reform individuals with 9 or fewer years of education looking observably "worse" than those prior to the reform. The variables we can look at include the log of family income and the educational attainment of the mothers and fathers (of our parents). The $\log$ of family income comes from the 1970 census and so is less than ideal for our purposes. However, when we regress each of these variables on the reform indicator along with cohort and municipality effects for the sample of individuals with 9 or fewer years of education, we find no evidence of any compositional change after the reform.

In return for making these additional assumptions and restricting the sample we are able to estimate a much stronger first stage and more precisely estimated second stage coefficients. $^{20}$

\section{Results}

Because of the timing of the reform, we balance the benefits of restricting our sample to older children (who are more likely to have completed their education by 2000) against the cost in terms of losing more children whose parents were directly affected by the reform. Our primary analysis will use the sample of children who were 20-35 in 2000, but we will also try restricting our sample to 25-35 year olds as a robustness check.

20 We have also tried using characteristics of the parents of our parents to split the sample based on predicted parental education rather than actual parental education. This approach gave us estimates that are 
We will place some emphasis on whether individuals have completed 12 years of education, as, by age 20 , the vast majority of individuals who will accumulate 12 years will have already done so. Note also that we are conditioning on age of child in the analysis.

\section{Results for the Full Sample}

The OLS results for equation (1) are presented in Table 3, Columns 1 and 3. They show, as expected, a positive relationship between the years of education of the parents and their child's education, whether the latter is measured in terms of years of education or an indicator equal to one if the child completed at least twelve years of education (the equivalent of a high school diploma). ${ }^{21}$ This is true, regardless of whether we match mothers to sons, mothers to daughters, fathers to sons, or fathers to daughters. Our estimates suggest that increasing a parent's education by a year increases the child's education by about 0.15 of a year. While the sample size varies, particularly between the father and mother regressions (due to our inability to match fathers who were not living with the family at the time of the 1960 census), our estimates are quite similar across samples.

Columns 2 and 4 then present our 2SLS results, where the instrument is the indicator for whether or not the father/mother was affected by the school reform in Norway. The 2SLS results are imprecisely estimated and are all statistically insignificant. The standard errors are sufficiently large that the 2SLS estimates are quite uninformative:

consistent with the ones we report but were very imprecisely estimated.

21 In both the OLS and 2SLS analysis we report robust standard errors that allow for clustering at the parent's municipality-parent's cohort level. To deal with possible concerns about the effects of serial correlation on the standard errors, we have also experimented with clustering by parent's municipality and 
one cannot rule out small or zero effects, and one also cannot generally rule out effects that are as large or larger than OLS. The main reason for the lack of precision is the weak first stage relationship between the reform and years of education of the father/mother: the t-statistics for the reform indicator in the first stage are about 5. (See Table 3a for the first stage estimates.) These relatively small t-statistics result from the fact that, while the reform has a large effect on the educational distribution for individuals with 9 years and less of education, it has very minor effects at higher education levels. It is clear that to effectively use the reform as a source of exogenous variation, one needs to focus on the very bottom tail of the education distribution, where the reform has bite.

\section{Results for the Restricted Sample}

The OLS estimates for the sample of parents with 9 or fewer years of education are in Columns 1 and 3 of Table 4. These are reasonably similar in magnitude to the OLS estimates for the full sample but tend to be a little higher. ${ }^{22}$ The first stage estimates are in Table 4a. Consistent with the evidence presented earlier, the first stage for the low education sample is much stronger than is the case for the full sample. The 2SLS estimates (Columns 2 and 4) are, as expected, much more precisely estimated than in the full sample. They are also universally smaller than the OLS estimates. This is particularly true for fathers: the estimates are all close to zero and statistically insignificant. For

\footnotetext{
found the 2SLS standard errors to be almost identical.

22 The OLS estimates may be slightly higher because, when we select individuals with less educated parents, the children are more likely to have finished their education by age 20. An offsetting factor is that, in this sample, the OLS estimates are more similar to the 2SLS estimates than would be the case from a conventional cross-sectional OLS regression. This is because individuals with 9 years of education postreform may have chosen fewer years of education in the absence of the reform. Hence, the positive correlation between education and unobserved ability that would tend to bias the OLS coefficients upwards is reduced by the presence of the reform. Indeed when we carry out OLS regression using only pre-reform observations, we find larger OLS coefficient values.
} 
mothers, the evidence suggests a positive effect of maternal education on the education of sons but no such relationship for daughters. Even the statistically significant mother/son coefficients are smaller than the OLS coefficients. Taken as a whole, the results indicate that the positive correlation between parent's and children's education largely represents positive relationships between other factors that are correlated with education. These could be ability, family background, income or other factors. The true causal effect of parental education on child education appears to be weak.

Our finding that the IV estimates are smaller than the OLS estimates makes sense because we expect education choice to be positively correlated with unobserved ability. However, this finding is not in keeping with much of the returns to education literature. Typically, IV estimates are found to be larger than OLS estimates. We suspect a few reasons for this divergence. First, our education data is of very high quality and probably has little or no measurement error. This is in contrast to the self-reported education data used in most studies. Thus, unlike in other studies, our OLS estimates may not be subject to downward biases due to measurement error. Second, our use of an education reform and our ability to control for both age and municipality effects leads to greater confidence that the instrument is not correlated with unobserved ability and hence our IV estimates are not upward biased. Finally, high IV estimates in the endogenous education literature are often rationalized by heterogeneous returns to education with particularly high returns for the group of people whose behavior is impacted by the instrument being used. Because credit constraints are unlikely to have been a major determinant of educational choice in the lower tail of the Norwegian distribution at this time, it is plausible that the returns to education for individuals impacted by the reform are no higher than the 
average. $^{23}$

\section{The Education of Both Parents}

So far, we have looked at the effects of mother's and father's education separately. These estimates take account of all ways in which one parent's education affects the child's education, including the effects of assortative mating -- that is, mother's education may affect child education both directly and also indirectly because highly educated mothers tend to marry more educated fathers. In this section, we include both mother's and father's education in the same specification. As such, we can separate out the direct effects of each parent's education from the indirect effects coming through assortative mating (which we will examine directly later in the paper). Because both mother's and father's education are endogenous, we need instruments for each of them. These are available to us because, since many individuals are of a different age or grew up in a different municipality than their spouse, the reform variable is potentially different for each spouse. For example, the husband may have gone to school pre-reform, but his younger wife may have been impacted by the reform.

When including both parents' education in the specification, the weak first stage when the full education distribution is used is an even greater problem than before. When we use the full sample, the estimates of both education variables are extremely imprecise. Once again, we need to make use of the fact that the reform only changed the education distribution in the lower tail. To do so, we use a sample of parental pairs such that at least

\footnotetext{
${ }^{23}$ Note that one might be concerned that the children of low-education parents will always get the minimum education mandated by law and, as a result, we will see all the children of the low-education parents clustered around 9 years of education. However, in fact this is not the case; only about $9 \%$ of the children's generation does the minimum of 9 years of education.
} 
one of the two parents had fewer than 10 years of schooling. This allows us to keep all individuals with fewer than 10 years of schooling in the sample and also to keep their spouses. We make one further change to the sample used earlier: Because mothers and fathers tend to differ in age, we do not restrict the sample to the reform cohorts but instead include any couple in which at least one of the two parents is in the reform cohorts. Thus, we do not exclude couples just because one of them was born outside of the reform cohorts.

Our results are presented in Table $5 .^{24}$ While our results are less precise, they are consistent with the results obtained in our earlier, separate regressions. OLS estimates suggest a positive relationship between parents' education and that of the children, with estimates for mother's education slightly larger than those for father's education.

However, IV estimates using the Norwegian school reform find no relationship between father's education and his children's education. (First stage results are presented in Table 5a.) We find some impact of mother's education on her children's education, although these estimates become statistically insignificant when we break the sample down into sons and daughters.

\section{Robustness/Specification Checks}

We have carried out numerous specification checks. As mentioned earlier, we have tried adding municipality-specific time trends and county-cohort fixed effects. To allow for possible mismeasurement of the exact timing of reform implementation, we have also tried dropping the reform year, and dropping the reform year and the years

24 Note that, similar to earlier specifications, we also include indicators for father's age, mother's age, father's municipality, mother's municipality, and child's age. 
immediately preceding and following it. None of these changes affected the results. Below we describe some more substantial specification checks.

Specification Check: Sample Selection

Given the population of data available from Statistics Norway, we were able to avoid many potential problems of sample selection. One selection criterion we do apply is to use children who are between 20-35 years old in 2000. One concern is that, by doing this, we may be including children who have not yet completed their education at the time of the survey. Given that our instrument is most effective for the lower end of the educational distribution (and less educated parents tend to have less educated children), it is unlikely that we are biasing our results much by including the younger

children. However, as a sensitivity check, we estimate the relationship between parents' and children's education on a subsample of 25-35 year olds whose parents have fewer than 10 years of education. These results are presented in Tables 6 and $6 \mathrm{a}$. Consistent with our earlier results, we find the same positive and significant relationship for mothers and sons but no evidence of a relationship for mothers and daughters or fathers and sons or daughters.

\section{Specification Check: Highly Educated}

The Norwegian education reform increased compulsory schooling from 7 to 9 years. As a result, we should see little effect of the reform on the educational attainment of more highly educated individuals. To verify this, we estimated our first and second stages on a subsample of individuals whose parents had completed at least 12 years of 
education. These results are presented in Tables 7 and $7 \mathrm{a}$. As expected, the first stage has no predictive power and the IV results are meaningless.

\section{Specification Check: Selection into Parenthood}

Another potential concern is the selection of individuals into parenthood. For example, suppose women with low human capital are more likely to become mothers, and this also varies by ability. That is, conditional on human capital, high ability women are less likely to have children. If the reform raises the human capital of a subgroup of women, then the high ability women in that subgroup may now choose not to have children. This would imply that the average ability level of mothers subject to the reform is lower than the average ability of mothers not subject to the reform. Hence, our IV results would be biased towards zero. One check on this possibility is to examine whether the reform affects the probability that an individual becomes a parent. If the reform has no impact on this probability, then it is unlikely to affect the sorting into parenthood by ability level.

Table 8 presents the results when we estimate a linear probability model on the sample of all individuals born between 1947-1958, with the dependent variable equal to one if the individual has one or more children in our sample of 20-35 year olds. Our variable of interest is the reform indicator. As always, we include municipality and cohort indicators in the specification. The results suggest that there is no relationship between the reform and the likelihood an individual has a child in our sample; the estimated coefficients are both economically small and statistically insignificant. 


\section{Sibling Fixed Effects}

The use of sibling fixed effects is common in the literature. While we are not convinced by the argument that education is exogenous conditional on these fixed effects, we consider it a useful exercise to see how inclusion of these controls affects the OLS results. If parent's education is positively related to unobserved ability, we would expect that inclusion of sibling fixed effects would reduce the OLS coefficients. Although there is no specific family identifier in our data, we can identify siblings as individuals with identical parents.

Table 9 presents the results when we estimate the relationship between parents' and children's education on same-sex sibling pairs of parents (Note that both siblings must have children in our sample to be included.) In this case, we are comparing differences in the educational attainment of brother or sister pairs and relating that difference to the difference in educational attainment of their children. ${ }^{25}$ Despite this seemingly restrictive sample selection, our sample sizes were still quite large, with at least 40,000 of each parent-child sex pairing. The OLS estimates are quite similar to those estimated on our full sample, and the fixed effects estimates are uniformly lower than the OLS estimates. Given that measurement error is not a major problem with our education data, we interpret these findings as suggesting that the OLS estimates are biased upwards because more able children or children with better family background are more likely to obtain more schooling. We don't put much faith in the siblings fixed effects estimates themselves because siblings with different levels of education are likely

25 Note that we also tried using sibling pairs and instrumenting for the parent's education using the educational reform. In this case, we are relating differences in educational attainment of two brothers or sisters induced by the reform to differences in educational attainment of their children. Unfortunately, our results were too imprecise to draw any conclusions. 
to have different ability levels. However, we see the estimates as providing more evidence that the true causal effect of parental education is lower than suggested by OLS estimates.

\section{Interpretation of the Results}

In the previous section, we found no evidence of a causal effect of father's education on child education but some evidence that mother's education affects the education of sons. Although theory provides very little guidance on this, we consider it plausible that mothers' education may matter more than fathers', given that children tend to spend much more time with their mother. It is more difficult to explain why mother's education may be more important to their sons than their daughters. ${ }^{26}$ In this section, we explore the mechanisms through which mothers' education may affect her child's education. The tone here is speculative, as there are many possible mechanisms and we have limited information with which to disentangle them.

The most direct mechanism is that extra schooling increases human capital of the mother and directly increases the optimal human capital choice of children. This could arise because the return to human capital is higher for individuals who have more educated parents or because the costs of human capital accumulation are lower (maybe because their parents can help them more with their schoolwork). While this direct mechanism is plausible, there are many alternative routes by which mothers' human capital can transmit into greater child education.

26 Interestingly, Chevalier (2003) also finds this result using British data. Furthermore, Fernandez et al. (2002) provide evidence that men's decisions in the marriage market are strongly influenced by the 


\section{The Man You Marry}

One possibility is that more educated women marry men who have more education, higher income, and greater ability than the men married by less educated women. If so, increasing a woman's education level may lead her children to have more education because of genetic transmission of traits from the chosen husband. ${ }^{27}$ Even in the absence of the genetic transmission, the husband's characteristics may impact the child's choice of schooling level. While we know that, in general, more educated women marry men with higher education and income levels, we now check whether this factor is driving our 2SLS results. To do so, we regress father's education and earnings on mother's education using the reform as instrument for mother's education. These results are presented in Table 10. We find the 2SLS estimates of the effects of mother's education on father's education and log earnings to be small and statistically insignificant for both the full sample and the sample of mothers with education of less than 10 years. $^{28}$ In contrast, as expected, the OLS estimates are significantly positive in each case.

The above evidence suggests that greater education induced by the reform did not have any major effect on the type of father chosen by the mother. This does not necessarily imply that it is mother's human capital per se that influences the child. Women with higher education have higher earnings, have higher labor market participation rates, and live in nicer neighborhoods. Unfortunately, given we only have one instrument, we cannot distinguish whether it is the additional human capital of the

characteristics of their mothers.

27 It would be difficult to square this kind of genetic explanation with the fact that we find mothers influence boy's behavior but not girls.

28 This occurs despite the fact that women are likely to marry men who may also have the same reform experience because they are similar in age and from the same area. This factor should trivially make it more likely we find positive 2SLS relationships between husband's and wife's education. 
mother itself or other factors that education gives rise to that matter.

\section{Quality/Quantity Tradeoff}

Yet another mechanism that could be at work is that women with more education may choose to have fewer children and to invest more in each one of them. We examine this mechanism by looking at the impact of mother's education on the total number of children each mother has. To do so, we regress the total number of children on mother's education using the reform as an instrument for mother's education. These results are

presented in Table $11{ }^{29}$ We present the results for the whole sample and then for the sample of mothers with fewer than 10 years of education, where our instrument has the most impact. The OLS results for the full sample (but not the low education sample) suggest that there is no effect of mother's education on the number of children she has, and the 2SLS results for both samples confirm this result. We therefore find no evidence of a tradeoff between quantity and quality of children as mothers acquire more education as a result of the reform.

\section{Conclusions}

We know that parents who are highly educated have children who, in turn, are highly educated. But how much of this is genetic? And how much is the direct effect of parental education on children's education choices? Understanding the causal effect of education on the educational decisions of later generations can provide a crucial piece of the puzzle in terms of understanding educational spillovers.

However, until now, we have been limited in our ability to determine the causal 
effect of parents' education on future generations. By applying the apparently random increase in educational attainment of some individuals due to a large change in compulsory schooling legislation in the 1960s and early 1970s in Norway to a unique dataset containing the entire population of the country, we are able to estimate the causal relationship between parents' education and that of their children.

Despite strong OLS relationships, we find little causal relationship between parent education and child education. The one exception is among mothers and sons; when mothers increase their educational attainment, their sons will get more education as well. These results are robust to a number of specification checks. In addition, we examined some of the possible mechanisms through which this relationship may be working, including whether the women who received more education due to the reform married better educated or wealthier men (they don't) and whether these more highly educated women are making a quantity/quality tradeoff (they aren't). While we are able to rule out a few mechanisms, a number remain, including the most direct, which suggests that higher education may reduce the cost (in terms of effort) of education for the child.

Despite this, these results suggest that intergenerational spillovers may not be a compelling argument for subsidizing education. However, it is important to remember that we are studying an education reform that increased education at the bottom tail of the distribution. It is plausible that a policy change that increased enrollment in higher education would have been transmitted more successfully across generations. While these results are compelling, much more work needs to be done on this important topic.

\footnotetext{
${ }^{29}$ Regressions also include age and municipality indicators.
} 
References

Aakvik, Arild, Kjell G. Salvanes, and Kjell Vaage. 2003. "Measuring the Heterogeneity in the Returns to Education in Norway Using Educational Reforms." CEPR DP 4088.

Acemoglu, Daron and Joshua Angrist. 1999. "How Large Are the Social Returns to Education? Evidence from Compulsory Schooling Laws." NBER Working Paper 7444.

Antonovics, Kate L. and Arthur S. Goldberger. 2003. "Do Educated Women Make Bad Mothers? Twin Studies and the Intergenerational Transmission of Human Capital." Mimeo.

Bjørklund, Anders and Markus Jantti. 1997. "Intergenerational Income Mobility in Sweden Compared to the United States." American Economic Review, 87(5), pp 1009-1018.

Björklund, Anders, Tor Eriksson, Markus Jännti, Oddbjørn Raaum and Erik Österbacka. 2002. "Brother correlations in earnings in Denmark, Finland, Norway and Sweden compared to the United States." Journal of Population Economics

Bratberg, Espen, Øivind Anti Nilsen, and Kjell Vaage. 2002. "Assessing Changes in Intergenerational Earnings Mobility." Centre for Economic Studies in Social Insurance Working Paper No. 54, University of Bergen, December.

Behrman, Jere R. and Mark R. Rosenzweig. 2002. "Does Increasing Women's Schooling Raise the Schooling of the Next Generation?" American Economic Review, 91(1), pp 323-334.

Bound, John and Gary Solon. 1999. "Double Trouble: On the Value of Twins-Based Estimation of the Returns to Schooling." Economics of Education Review, 18, pp 169-182.

Currie, Janet and Enrico Morietti. 2003. "Mother's Education and the Intergenerational Transmission of Human Capital: Evidence from College Openings." Quarterly Journal of Economics, forthcoming.

Chevalier, Arnaud. 2003. "Parental Education and Child's Education: A Natural Experiment." Mimeo, University College Dublin.

Dearden, L, S. Machin and H. Reed. 1997. "Intergenerational Mobility in Britain." Economic Journal, 107, 47-66.

Fernandez, Raquel, Alessandra Fogli, and Claudia Olivetti. 2002. "Marrying Your Mom: 
Preference Transmission and Women's Labor and Education Choices" NBER Working Paper \#9234.

Griliches, Zvi. 1979. "Sibling Models and Data in Economics: Beginnings of a Survey." Journal of Political Economy, 87, pp 37-64.

Harmon, C. and Ian Walker. 1995. "Estimates of the Economic Return to Schooling for the United Kingdom." American Economic Review, 85, 1278-86.

Leschinsky, A. and Mayer, K. A. (eds.) (1990). The Comprehensive School Experiment Revisited: Evidence from Western Europe. Frankfurt am Main.

Lie, Suzanne S. (1973) The Norwegian Comprehensive School Reform. Strategies for Implementation and Complying with Regulated Social Change. A Diffusion Study. Part 1 and II. Washington, D.C., The American University.

Lie, Suzanne S. (1974) "Regulated Social Change: a Diffusion Study of the Norwegian Comprehensive School Reform”, Acta Sociologica, 16(4), 332-350.

Lindbekk, Tore (1992) "School Reforms in Norway and Sweden and the Redistribution of Educational Attainment." Journal of Educational Research, 37(2), 129-49.

Mediås, Olav A. (2000). Fra griffel til PC. In Norwegian. (From pencil to PC). Steinkjer: Steinkjer kommune.

Meghir, Costas and Marten Palme. 2003. "Ability, parenthal background and education policy: empirical evidence from a social experiment", mimeo, Stockholm School of Economics.

Mulligan, C. 1999. "Galton versus the human capital approach to inheritance." Journal of Political Economy, 107, 184-224.

Møen, Jarle, Kjell G. Salvanes and Erik Ø. Sørensen. 2003. "Documentation of the Linked Empoyer-Employee Data Base at the Norwegian School of Economics." Mimeo, The Norwegian School of Economics and Business Administration.

Ness, Erik (ed.). (1971). Skolens Årbok 1971. In Norwegian. (The primary school yearbook 1971.) Oslo: Johan Grundt Tanum Forlag.

Oreopoulos, P. 2003. “Do dropouts drop out too soon?” Mimeo, University of Toronto,.

Plug, Erik. 2002. "How do Parents Raise the Educational Attainment of Future Generations?", IZA Discussion Paper No. 652.

Raaum, O., Salvanes, K.G. and Sørensen, E. Ø. (2001). "The Neighbourhood is not what it used to be. Discussion paper 36/2001, The Norwegian School of Economics and 
Business Administration.

Raaum, Oddbjørn, Kjell G. Salvanes, Erik Ø. Sørensen (2003) "The Impact of a Primary School Reform on Social stratification: A Norwegian study of Neighbour and School Mate Correlations." The Swedish Journal of Economic Policy, 8(2).

Sacerdote, Bruce (2002). "The Nature and Nurture of Economic Outcomes." American Economic Review, 92(2), pp 344-348.

Solon, Gary (1999). "Intergenerational Mobility in the Labor Market." In Handbook of Labor Economics, Volume 3. O. Ashenfelter and D. Card, editors. pp 17611800.

Telhaug, Arne O. (1969). Den 9-årige skolen og differensieringsproblemet. En oversikt over den historiske utvikling og den aktuelle debatt. In Norwegian. (The 9-years compulsory school and the tracking problem. An overview of the historical development and the current debate). Oslo: Lærerstudentenes Forlag. 


\section{Table 1: Summary Statistics}

\begin{tabular}{lrrr}
\hline & Observations & \multicolumn{1}{c}{ Mean } & Std. Dev. \\
\hline Children & & & \\
Age & 351,086 & 24.80 & 3.50 \\
Education & 351,086 & 11.94 & 1.61 \\
Earnings & 351,086 & 159,594 & 124,842 \\
Sex (Female / Male) & 351,086 & 0.49 & 0.50 \\
Mothers & & & \\
Age & 286,137 & 48.34 & 3.12 \\
Education & 286,137 & 10.88 & 2.37 \\
Earnings & 282,922 & 182,017 & 120,774 \\
Fathers & & & \\
Age & 228,060 & 49.29 & 2.86 \\
Education & 228,060 & 11.43 & 2.66 \\
Earnings & 222,405 & 331,301 & 506,507 \\
\hline
\end{tabular}

Sample includes children who were between the ages of 20 and 35 in 2000 who had at least one parent born during the reform period. Parental age and education are reported only for parents who are members of the reform cohorts. 


\section{Table 2: Distribution of Education Two Years Before and After the Reform}

\begin{tabular}{lrr}
\hline $\begin{array}{l}\text { Years of } \\
\text { Education }\end{array}$ & \multicolumn{1}{l}{ Before } & \multicolumn{1}{l}{ After } \\
\hline 7 & $3.5 \%$ & $1.2 \%$ \\
8 & $8.9 \%$ & $1.6 \%$ \\
9 & $3.4 \%$ & $12.9 \%$ \\
10 & $29.5 \%$ & $26.6 \%$ \\
11 & $8.5 \%$ & $8.9 \%$ \\
12 & $17.2 \%$ & $19.1 \%$ \\
13 & $6.7 \%$ & $6.6 \%$ \\
14 & $5.4 \%$ & $5.8 \%$ \\
15 & $2.7 \%$ & $3.4 \%$ \\
$16+$ & $14.2 \%$ & $14.1 \%$ \\
$\mathrm{~N}$ & 89,320 & 92,227 \\
\hline
\end{tabular}

Before indicates education distribution of cohorts in the two years prior to the reform, while After indicates the distribution of those two years post reform. Note that, because the reform occurred in different municipalities at different times, the actual year of the reform varies by municipality. 


\section{Table 3: Relationship between Parents' and Children's Education Full Sample}

\begin{tabular}{|c|c|c|c|c|c|c|}
\hline & \multicolumn{6}{|c|}{ Dependent Variable } \\
\hline & \multicolumn{3}{|c|}{ Years of Education } & \multicolumn{3}{|c|}{ Education $>12$ Years } \\
\hline & OLS & & IV & OLS & & IV \\
\hline Mother - All & 0.1578 & $*$ & 0.0414 & 0.0388 & $*$ & -0.0018 \\
\hline $\mathrm{N}=286,137$ & $(0.0022)$ & & $(0.0955)$ & $(0.0004)$ & & $(0.0283)$ \\
\hline Mother - Son & 0.1459 & $*$ & 0.0202 & 0.0391 & $*$ & 0.0052 \\
\hline $\mathrm{N}=147,005$ & $(0.0026)$ & & $(0.1260)$ & $(0.0005)$ & & $(0.0406)$ \\
\hline Mother - Daughter & 0.1703 & $*$ & 0.0550 & 0.0385 & $*$ & -0.0087 \\
\hline $\mathrm{N}=139,132$ & $(0.0025)$ & & $(0.1259)$ & $(0.0005)$ & & $(0.0356)$ \\
\hline Father - All & 0.1387 & $*$ & 0.0343 & 0.0368 & $*$ & 0.0156 \\
\hline $\mathrm{N}=228,060$ & $(0.0016)$ & & $(0.0745)$ & $(0.0004)$ & & $(0.0236)$ \\
\hline Father - Son & 0.1369 & $*$ & 0.1034 & 0.0388 & $*$ & 0.0561 \\
\hline $\mathrm{N}=117,372$ & $(0.0019)$ & & $(0.0889)$ & $(0.0005)$ & & $(0.0316)$ \\
\hline Father - Daughter & 0.1408 & $*$ & -0.0420 & 0.0347 & $*$ & -0.0337 \\
\hline $\mathrm{N}=110,688$ & $(0.0020)$ & & $(0.1132)$ & $(0.0005)$ & & $(0.0353)$ \\
\hline
\end{tabular}

Sample includes children aged 20-35. Robust standard errors in parentheses. Each estimate represents the coefficient from a different regression. All specifications include dummies for parent's age, parent's municipality, and child's age.

*significant at $5 \%$

Table 3a: First Stage Results Full Sample

\begin{tabular}{lrlrl}
\hline & $\begin{array}{c}\text { Mother's } \\
\text { Education }\end{array}$ & $\begin{array}{c}\text { Father's } \\
\text { Education }\end{array}$ \\
\hline All & 0.1133 & $*$ & 0.1595 & $*$ \\
& $(0.0208)$ & & $(0.0291)$ & \\
Son & 0.1058 & $*$ & 0.1689 & $*$ \\
& $(0.0249)$ & & $(0.0343)$ & \\
Daughter & 0.1219 & $*$ & 0.1527 & $*$ \\
& $(0.0248)$ & & $(0.0346)$ & \\
\hline
\end{tabular}

Robust standard errors in parentheses. Each estimate represents the coefficient from a different regression. First stage also includes dummies for parent's age, parent's municipality, and child's age. *significant at $5 \%$ 


\section{Table 4: Relationship between Parents' and Children's Education Parents with $<10$ Years Education}

\begin{tabular}{|c|c|c|c|c|c|c|c|}
\hline & \multicolumn{7}{|c|}{ Dependent Variable } \\
\hline & \multicolumn{3}{|c|}{ Years of Education } & & \multicolumn{3}{|c|}{ Education $>12$ Years } \\
\hline & OLS & & IV & & OLS & & IV \\
\hline Mother - All & 0.1844 & $*$ & 0.0786 & $*$ & 0.0509 & $*$ & 0.0197 \\
\hline $\mathrm{N}=63,269$ & $(0.0130)$ & & $(0.0316)$ & & $(0.0040)$ & & $(0.0103)$ \\
\hline Mother - Son & 0.1743 & $*$ & 0.1051 & $*$ & 0.0484 & $*$ & 0.0206 \\
\hline $\mathrm{N}=32,247$ & $(0.0158)$ & & $(0.0388)$ & & $(0.0052)$ & & $(0.0136)$ \\
\hline Mother - Daughter & 0.1935 & $*$ & 0.0480 & & 0.0521 & $*$ & 0.0166 \\
\hline $\mathrm{N}=31,022$ & $(0.0182)$ & & $(0.0444)$ & & $(0.0055)$ & & $(0.0136)$ \\
\hline Father - All & 0.1642 & $*$ & 0.0468 & & 0.0462 & $*$ & 0.0126 \\
\hline $\mathrm{N}=43,407$ & $(0.0132)$ & & $(0.0344)$ & & $(0.0043)$ & & $(0.0118)$ \\
\hline Father - Son & 0.1403 & $*$ & 0.0366 & & 0.0406 & $*$ & 0.0150 \\
\hline $\mathrm{N}=22,059$ & $(0.0166)$ & & $(0.0402)$ & & $(0.0060)$ & & $(0.0154)$ \\
\hline Father - Daughter & 0.1844 & $*$ & 0.0516 & & 0.0515 & $*$ & 0.0099 \\
\hline $\mathrm{N}=21,348$ & $(0.0201)$ & & $(0.0509)$ & & $(0.0064)$ & & $(0.0162)$ \\
\hline
\end{tabular}

Robust standard errors in parentheses. Each estimate represents the coefficient from a different regression. All specifications include dummies for parent's age, parent's municipality, and child's age.

*significant at $5 \%$

\begin{tabular}{lrrrr}
\multicolumn{4}{c}{ Table 4a: First Stage Results } \\
Parents with $<\mathbf{1 0}$ Years of Education \\
\hline $\begin{array}{c}\text { Mother's } \\
\text { Education }\end{array}$ & $\begin{array}{c}\text { Father's } \\
\text { Education }\end{array}$ \\
\hline All & 0.7329 & $*$ & 0.7777 & $*$ \\
& $(0.0155)$ & $(0.0204)$ & \\
Son & 0.7142 & $*$ & 0.7881 & $*$ \\
& $(0.0173)$ & & $(0.0229)$ & \\
Daughter & 0.7504 & $*$ & 0.7702 & $*$ \\
& $(0.0172)$ & & $(0.0225)$ & \\
\hline
\end{tabular}

Robust standard errors in parentheses. Each estimate represents the coefficient from a different regression. First stage also includes dummies for parent's age, parent's municipality, and child's age. *significant at 5\% 


\section{Table 5: Relationship between Parents' and Children's Education Including Both Parents' Education If Either Parent Has $<10$ Years Education}

\begin{tabular}{|c|c|c|c|c|c|c|}
\hline \multirow[t]{2}{*}{$\begin{array}{l}\text { Dependent Variable: } \\
\text { Years of Education }\end{array}$} & \multicolumn{2}{|c|}{ All Children } & \multicolumn{2}{|c|}{ Sons } & \multicolumn{2}{|c|}{ Daughters } \\
\hline & OLS & IV & OLS & IV & OLS & IV \\
\hline Mother' Education & $\begin{array}{l}.15^{*} \\
(.004)\end{array}$ & $\begin{array}{l}.16^{*} \\
(.06)\end{array}$ & $\begin{array}{l}.13^{*} \\
(.005)\end{array}$ & $\begin{array}{c}.28 \\
(.50)\end{array}$ & $\begin{array}{l}.18^{*} \\
(.01)\end{array}$ & $\begin{array}{l}.13 \\
(.08)\end{array}$ \\
\hline Father's Education & $\begin{array}{l}.11^{*} \\
(.003)\end{array}$ & $\begin{array}{l}-.01 \\
(.07)\end{array}$ & $\begin{array}{l}.11^{*} \\
(.004)\end{array}$ & $\begin{array}{l}-.07 \\
(.39)\end{array}$ & $\begin{array}{l}.12^{*} \\
(.01)\end{array}$ & $\begin{array}{l}-.03 \\
(.09)\end{array}$ \\
\hline $\mathrm{N}$ & \multicolumn{2}{|c|}{76,649} & \multicolumn{2}{|c|}{39,150} & \multicolumn{2}{|c|}{37,499} \\
\hline
\end{tabular}

Each column represents a separate regression. Regressions also include indicators for mother's age, father's age, mother's municipality, father's municipality, and child's age. Robust standard errors in parentheses. Sample includes children 20-35 years of age who had at least one parent born in the reform cohorts. * significant at $5 \%$ level.

\section{Table 5a: First Stage Results If Either Parent Has < 10 Years Education}

\begin{tabular}{|c|c|c|c|c|c|c|}
\hline & \multicolumn{2}{|c|}{ All Children } & \multicolumn{2}{|c|}{ Sons } & \multicolumn{2}{|c|}{ Daughters } \\
\hline & $\begin{array}{l}\text { Mother's } \\
\text { Education }\end{array}$ & $\begin{array}{c}\text { Father's } \\
\text { Education }\end{array}$ & $\begin{array}{c}\text { Mother's } \\
\text { Education }\end{array}$ & $\begin{array}{c}\text { Father's } \\
\text { Education }\end{array}$ & $\begin{array}{c}\text { Mother's } \\
\text { Education }\end{array}$ & $\begin{array}{c}\text { Father's } \\
\text { Education }\end{array}$ \\
\hline Mother Reform $=1$ & $\begin{array}{c}0.3876^{*} \\
(0.0202)\end{array}$ & $\begin{array}{r}-0.0495^{*} \\
(0.0198)\end{array}$ & $\begin{array}{c}0.3636 * \\
(0.0286)\end{array}$ & $\begin{array}{r}-0.0477 \\
(0.0279)\end{array}$ & $\begin{array}{c}0.4191 * \\
(0.0288)\end{array}$ & $\begin{array}{c}-0.0593 * \\
(0.0287)\end{array}$ \\
\hline Father Reform $=1$ & $\begin{array}{c}0.0423 * \\
(0.0170)\end{array}$ & $\begin{array}{c}0.3347 * \\
(0.0256)\end{array}$ & $\begin{array}{r}0.0450 \\
(0.0240)\end{array}$ & $\begin{array}{c}0.3097 * \\
(0.0359)\end{array}$ & $\begin{array}{r}0.0419 \\
(0.0245)\end{array}$ & $\begin{array}{c}0.3558 * \\
(0.0373)\end{array}$ \\
\hline $\mathrm{N}$ & 76 & & 39 & 50 & 37 & 99 \\
\hline
\end{tabular}

Each column represents one regression. Note that there are two first stage regressions, one for each parents' education; each first stage regression included an indicator for whether the mother was affected by the reform and an indicator for whether the father was affected by the reform. Regressions also include indicators for mother's age, father's age, mother's municipality, father's municipality, and child's age. Robust standard errors in parentheses. Sample includes children 20-35 years of age who had at least one parent born in the reform cohorts. * significant at $5 \%$ level. 


\section{Table 6: Relationship between Parents' and Children's Education Parents with $<10$ Years Education 25-35 Year Old Children}

\begin{tabular}{|c|c|c|c|c|c|c|c|c|}
\hline & \multicolumn{8}{|c|}{ Dependent Variable } \\
\hline & \multicolumn{3}{|c|}{ Years of Education } & & \multicolumn{4}{|c|}{ Education $>12$ Years } \\
\hline & OLS & & IV & & OLS & & IV & \\
\hline Mother - All & 0.2111 & $*$ & 0.1216 & $*$ & 0.0546 & $*$ & 0.0319 & $*$ \\
\hline $\mathrm{N}=40,098$ & $(0.0169)$ & & $(0.0432)$ & & $(0.0048)$ & & $(0.0130)$ & \\
\hline Mother-Son & 0.1970 & $*$ & 0.1764 & $*$ & 0.0512 & $*$ & 0.0480 & $*$ \\
\hline $\mathrm{N}=20,135$ & $(0.0213)$ & & $(0.0544)$ & & $(0.0065)$ & & $(0.0177)$ & \\
\hline Mother-Daughter & 0.2246 & $*$ & 0.0662 & & 0.0569 & $*$ & 0.0162 & \\
\hline $\mathrm{N}=19,470$ & $(0.0235)$ & & $(0.0631)$ & & $(0.0064)$ & & $(0.0175)$ & \\
\hline Father - All & 0.2000 & $*$ & 0.0408 & & 0.0488 & $*$ & 0.0133 & \\
\hline $\mathrm{N}=22,148$ & $(0.0215)$ & & $(0.0618)$ & & $(0.0061)$ & & $(0.0176)$ & \\
\hline Father - Son & 0.1513 & $*$ & 0.0078 & & 0.0381 & $*$ & 0.0129 & \\
\hline $\mathrm{N}=11,235$ & $(0.0274)$ & & $(0.0714)$ & & $(0.0086)$ & & $(0.0237)$ & \\
\hline Father - Daughter & 0.2438 & $*$ & 0.0806 & & 0.0581 & $*$ & 0.0067 & \\
\hline $\mathrm{N}=10,913$ & $(0.0329)$ & & $(0.0936)$ & & $(0.0089)$ & & $(0.0249)$ & \\
\hline
\end{tabular}

Each estimate represents the coefficient from a different regression. All specifications include dummies for parent's age, parent's municipality, and child's age. Robust standard errors in parentheses.

*significant at $5 \%$

Table 6a: First Stage Results

Parents with $<10$ Years of Education

25-35 Year old Children

\begin{tabular}{lrlrl}
\hline & $\begin{array}{c}\text { Mother's } \\
\text { Education }\end{array}$ & $\begin{array}{c}\text { Father's } \\
\text { Education }\end{array}$ \\
\hline All & 0.7494 & $*$ & 0.7952 & $*$ \\
& $(0.0166)$ & & $(0.0240)$ & \\
Son & 0.7419 & $*$ & 0.8139 & $*$ \\
& $(0.0194)$ & & $(0.0287)$ & \\
Daughter & 0.7552 & $*$ & 0.7792 & $*$ \\
& $(0.0192)$ & & $(0.0274)$ & \\
\hline
\end{tabular}

Each estimate represents the coefficient from a different regression. Robust standard errors in parentheses. First stage also includes dummies for parent's age, parent's municipality, and child's age. *significant at $5 \%$ 


\section{Table 7: Relationship between Parents' and Children's Education Parents with at Least 12 Years of Education}

\begin{tabular}{|c|c|c|c|c|c|c|}
\hline & \multicolumn{6}{|c|}{ Dependent Variable } \\
\hline & \multicolumn{3}{|c|}{ Years of Education } & \multicolumn{3}{|c|}{ Education $>12$ Years } \\
\hline & OLS & & IV & OLS & & IV \\
\hline Mother - All & 0.1080 & $*$ & -0.3900 & 0.0204 & $*$ & -0.0161 \\
\hline $\mathrm{N}=89,193$ & $(0.0031)$ & & $(0.3537)$ & $(0.0008)$ & & $(0.0728)$ \\
\hline Mother - Son & 0.0994 & $*$ & -0.5182 & 0.0213 & $*$ & -0.1037 \\
\hline $\mathrm{N}=46,056$ & $(0.0041)$ & & $(0.6943)$ & $(0.0012)$ & & $(0.1808)$ \\
\hline Mother - Daughter & 0.1180 & $*$ & -0.3235 & 0.0193 & $*$ & 0.0309 \\
\hline $\mathrm{N}=43,137$ & $(0.0046)$ & & $(0.3575)$ & $(0.0010)$ & & $(0.0726)$ \\
\hline Father - All & 0.1255 & $*$ & 1.1959 & 0.0280 & $*$ & 0.6184 \\
\hline $\mathrm{N}=106,989$ & $(0.0026)$ & & $(3.5369)$ & $(0.0006)$ & & $(1.7587)$ \\
\hline Father - Son & 0.1262 & $*$ & 2.7932 & 0.0307 & $*$ & 42.5819 \\
\hline $\mathrm{N}=55,359$ & $(0.0033)$ & & $(13.6391)$ & $(0.0009)$ & & $(12.5947)$ \\
\hline Father - Daughter & 0.0795 & $*$ & -0.2261 & 0.0130 & $*$ & -0.0913 \\
\hline $\mathrm{N}=25,446$ & $(0.0047)$ & & $(0.9185)$ & $(0.0011)$ & & $(0.2593)$ \\
\hline
\end{tabular}

Each estimate represents the coefficient from a different regression. All specifications include dummies for parent's age, parent's municipality, and child's age. Robust standard errors in parentheses.

*significant at $5 \%$

\begin{tabular}{|c|c|c|c|}
\hline & $\begin{array}{l}\text { Mother's } \\
\text { Education }\end{array}$ & & $\begin{array}{c}\text { Father's } \\
\text { Education }\end{array}$ \\
\hline All & $\begin{array}{r}-0.0648 \\
(0.0293)\end{array}$ & $*$ & $\begin{array}{r}0.0102 \\
(0.0290)\end{array}$ \\
\hline Son & $\begin{array}{r}-0.0445 \\
(0.0358)\end{array}$ & & $\begin{array}{r}0.0073 \\
(0.0360)\end{array}$ \\
\hline Daughter & $\begin{array}{r}-0.0860 \\
(0.0355)\end{array}$ & $*$ & $\begin{array}{r}-0.0395 \\
(0.0504)\end{array}$ \\
\hline
\end{tabular}

Each estimate represents the coefficient from a different regression. Robust standard errors in parentheses. First stage also includes dummies for parent's age, parent's municipality, and child's age. *significant at $5 \%$ 
Table 8:

Probability of Having a Child in the Sample

\begin{tabular}{lcr}
\hline Full Sample & $\begin{array}{r}\text { Education } \\
<\mathbf{1 0} \text { years }\end{array}$ \\
\hline Mothers & -0.0038 & 0.0009 \\
& $(0.0040)$ & $(0.0066)$ \\
Fathers & $\mathrm{N}=260,674$ & $\mathrm{~N}=42,026$ \\
& 0.0077 & -0.0018 \\
$(0.0040)$ & $(0.0078)$ \\
& $\mathrm{N}=292,749$ & $\mathrm{~N}=45,591$ \\
\hline
\end{tabular}

Estimates represent coefficients in a linear probability model; each estimate represents the coefficient from a different regression. All specifications include dummies for parent's age and parent's municipality. Robust standard errors in parentheses.

*significant at $5 \%$ 


\section{Table 9: Relationship between Parents' and Children's Education Sibling Fixed Effects}

\begin{tabular}{|c|c|c|c|c|c|c|c|c|}
\hline & \multicolumn{7}{|c|}{ Dependent Variable } & \\
\hline & \multicolumn{3}{|c|}{ Years of Education } & & \multicolumn{4}{|c|}{ Education $>12$ Years } \\
\hline & OLS & & $\mathbf{F E}$ & & OLS & & FE & \\
\hline Mother - All & 0.1419 & $*$ & 0.0725 & $*$ & 0.0364 & $*$ & 0.0166 & $*$ \\
\hline $\mathrm{N}=90,902$ & $(0.0022)$ & & $(0.0038)$ & & $(0.0006)$ & & $(0.0011)$ & \\
\hline Mother-Son & 0.1330 & $*$ & 0.0681 & $*$ & 0.0374 & $*$ & 0.0168 & $*$ \\
\hline $\mathrm{N}=46,889$ & $(0.0029)$ & & $(0.0057)$ & & $(0.0008)$ & & $(0.0018)$ & \\
\hline Mother - Daughter & 0.1515 & $*$ & 0.0798 & $*$ & 0.0355 & $*$ & 0.0149 & $*$ \\
\hline $\mathrm{N}=44,013$ & $(0.0032)$ & & $(0.0064)$ & & $(0.0008)$ & & $(0.0017)$ & \\
\hline Father - All & 0.1345 & $*$ & 0.0731 & $*$ & 0.0373 & $*$ & 0.0185 & $*$ \\
\hline $\mathrm{N}=82,894$ & $(0.0019)$ & & $(0.0036)$ & & $(0.0005)$ & & $(0.0011)$ & \\
\hline Father - Son & 0.1361 & $*$ & 0.0823 & $*$ & 0.0399 & $*$ & 0.0218 & $*$ \\
\hline $\mathrm{N}=42,736$ & $(0.0025)$ & & $(0.0054)$ & & $(0.0008)$ & & $(0.0018)$ & \\
\hline Father - Daughter & 0.1329 & $*$ & 0.0579 & $*$ & 0.0345 & $*$ & 0.0136 & $*$ \\
\hline $\mathrm{N}=40,158$ & $(0.0027)$ & & $(0.0063)$ & & $(0.0007)$ & & $(0.0018)$ & \\
\hline
\end{tabular}

Regressions include same-sex sibling pairs. Estimates represent the relationship between the difference in education of two same-sex siblings and the difference in education between their same-sex children, controlling for indicators of parent's age and child's age. Robust standard errors in parentheses.

*significant at $5 \%$ 


\section{Table 10: Relationship between Mother's Education and Father's Earnings/ Education}

\begin{tabular}{|c|c|c|c|c|c|c|}
\hline \multirow{3}{*}{ Mother's Education } & \multicolumn{6}{|c|}{ Dependent Variable } \\
\hline & \multicolumn{3}{|c|}{ Father's Education } & \multicolumn{3}{|c|}{ Log Father's Earnings } \\
\hline & OLS & & IV & OLS & & IV \\
\hline \multirow[t]{3}{*}{ Full Sample } & 0.5153 & $*$ & 0.1807 & 0.0428 & $*$ & -0.0347 \\
\hline & $(0.0061)$ & & $(0.2481)$ & $(0.0008)$ & & $(0.0635)$ \\
\hline & $\mathrm{N}=127,141$ & & $\mathrm{~N}=127,141$ & $\mathrm{~N}=114,023$ & & $\mathrm{~N}=114,023$ \\
\hline \multirow[t]{3}{*}{ Education $<10$ Years } & 0.2127 & $*$ & 0.0808 & 0.0417 & $*$ & -0.0037 \\
\hline & $(0.0276)$ & & $(0.0587)$ & $(0.0083)$ & & $(0.0200)$ \\
\hline & $\mathrm{N}=24,692$ & & $\mathrm{~N}=24,692$ & $\mathrm{~N}=20,930$ & & $\mathrm{~N}=20,930$ \\
\hline
\end{tabular}


Table 11: Relationship between Number of Children and Mother's Education

\begin{tabular}{lrr}
\hline Dependent Variable: & \multicolumn{2}{c}{ Number of Children } \\
\cline { 2 - 3 } & OLS & IV \\
\hline Mother's Education & 0.0014 & -0.0185 \\
Full Sample & $(0.0015)$ & $(0.0789)$ \\
& $\mathrm{N}=165,448$ & $\mathrm{~N}=165,448$ \\
Mother's Education & $-0.0296 * *$ & -0.0039 \\
Education $<10$ Years & $(0.0087)$ & $(0.0210)$ \\
& $\mathrm{N}=33,787$ & $\mathrm{~N}=33,787$ \\
\hline
\end{tabular}

Each estimate represents the coefficient from a separate regression of number of children on mother's education. All specifications include dummies for mother's age and mother's municipality. Robust standard errors in parentheses.

*significant at $5 \%$ 
Figure 1

The Number of Municipalities Implementing the Education Reform, by Year

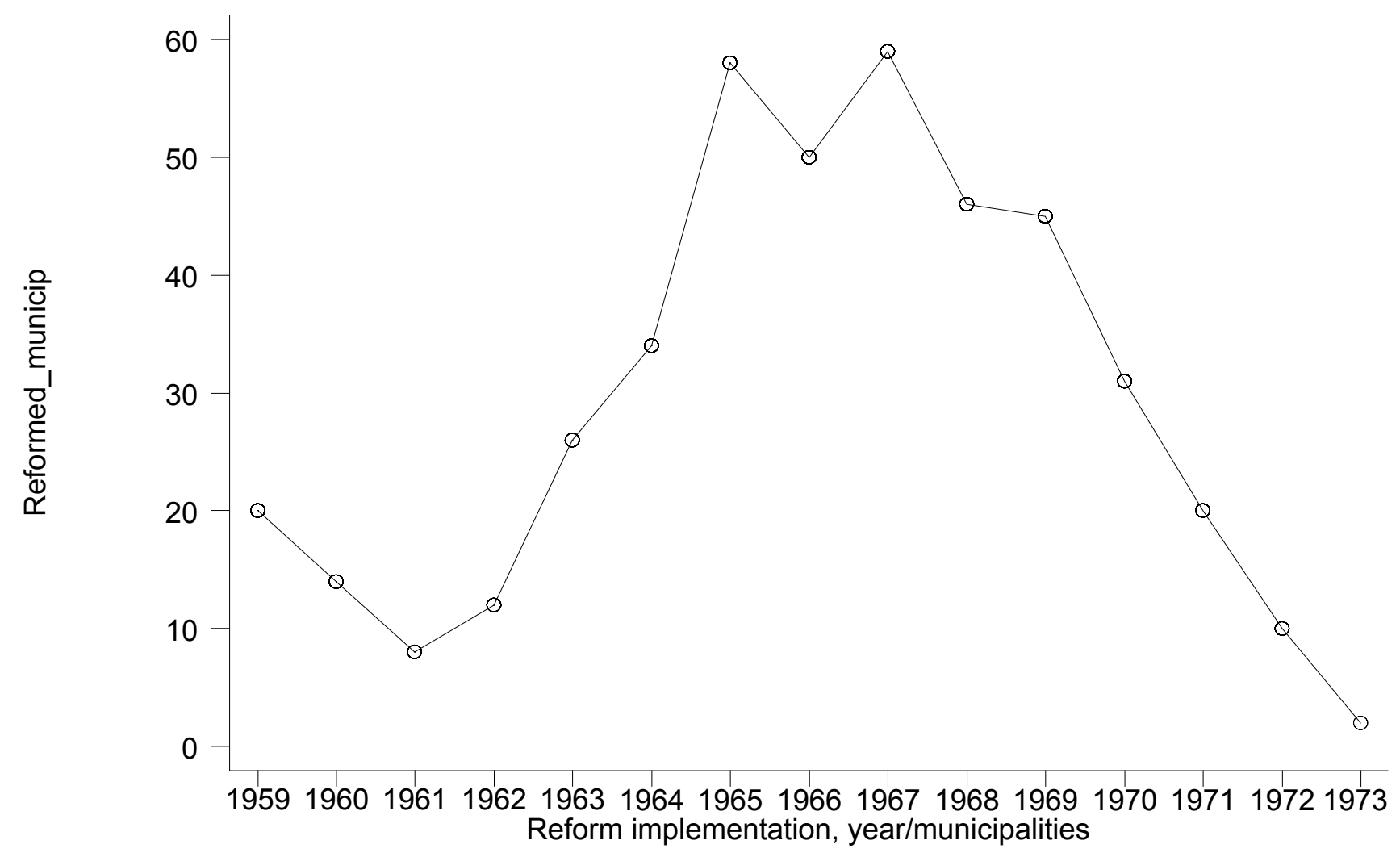


Figure 2

Reform implementation in Poor vs Rich Municipalities

Based on Average Family Income.

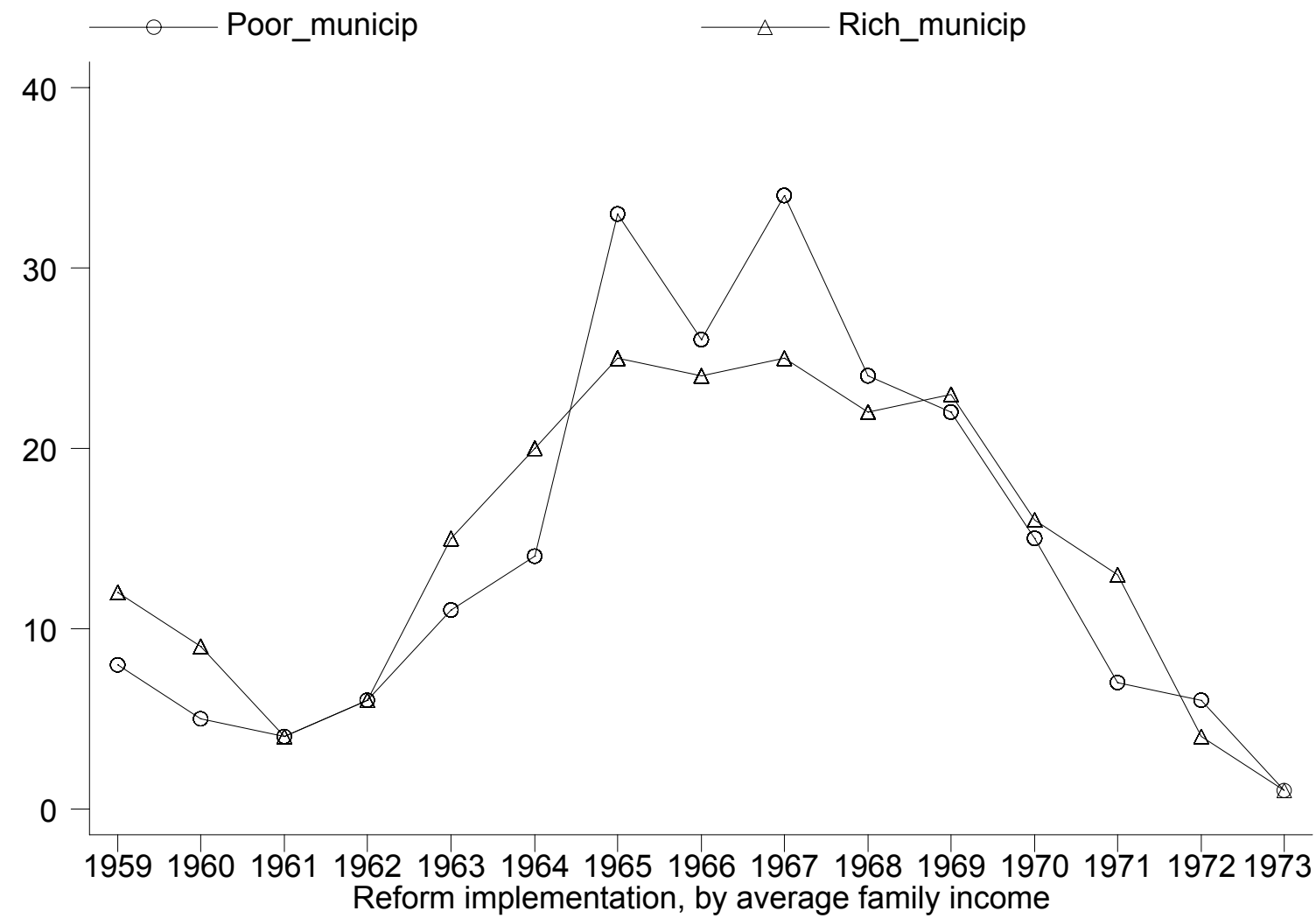

Poor (rich) municipality is calculated as below (above) median parent's income by municipality Parent's average income is calculated for each municipality in 1970. 
Figure 3

Reform Implementation in High vs. Low Education Municipalities

Based on Average Years Father's of Education in the Municipality

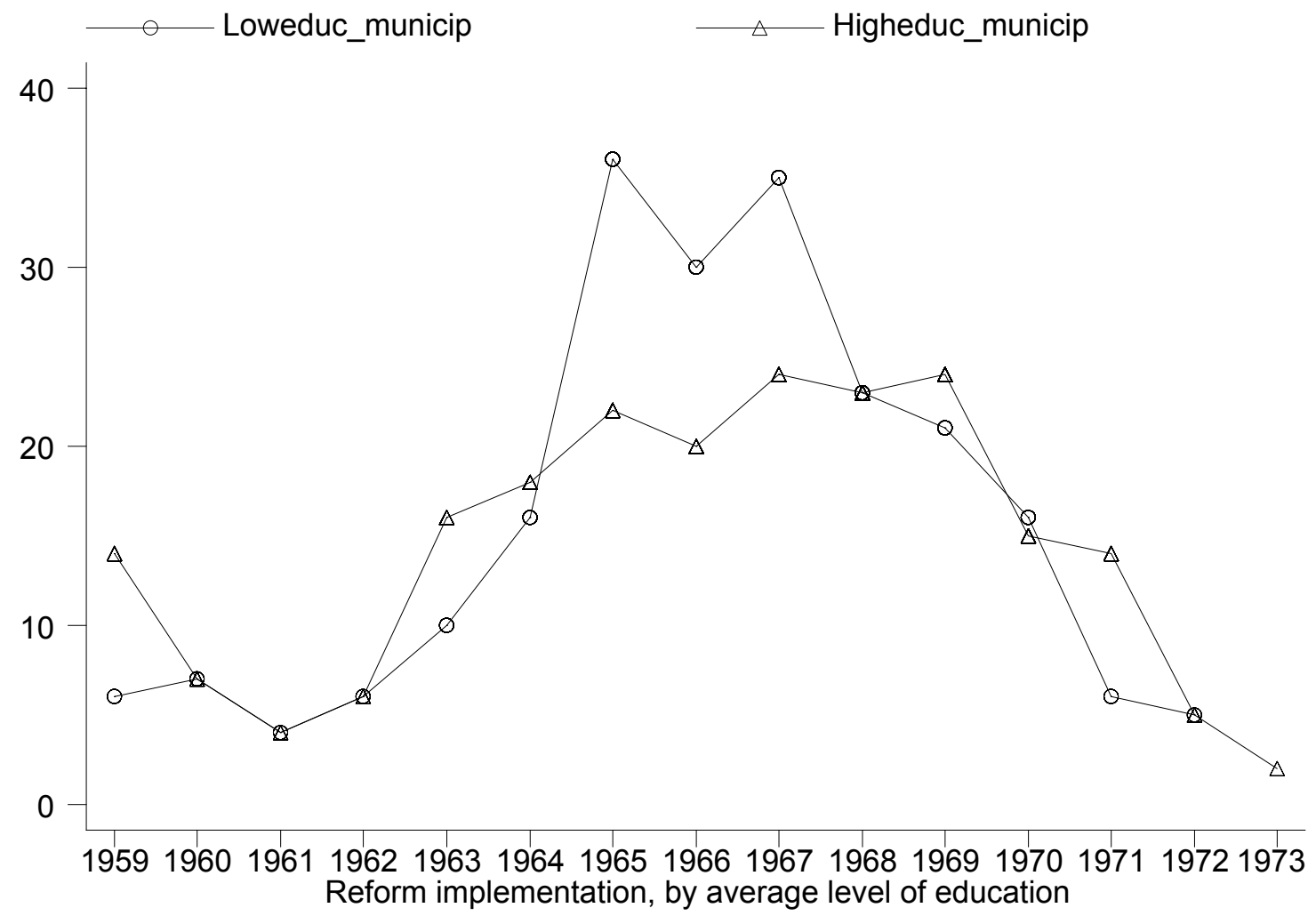

Low (high) education municipality is calculated as below (above) median education by municipality. Father's average years of education is calculated for each municipality in 1960. 
Figure 4

Reform Implementation in Small vs. Large Municipalities

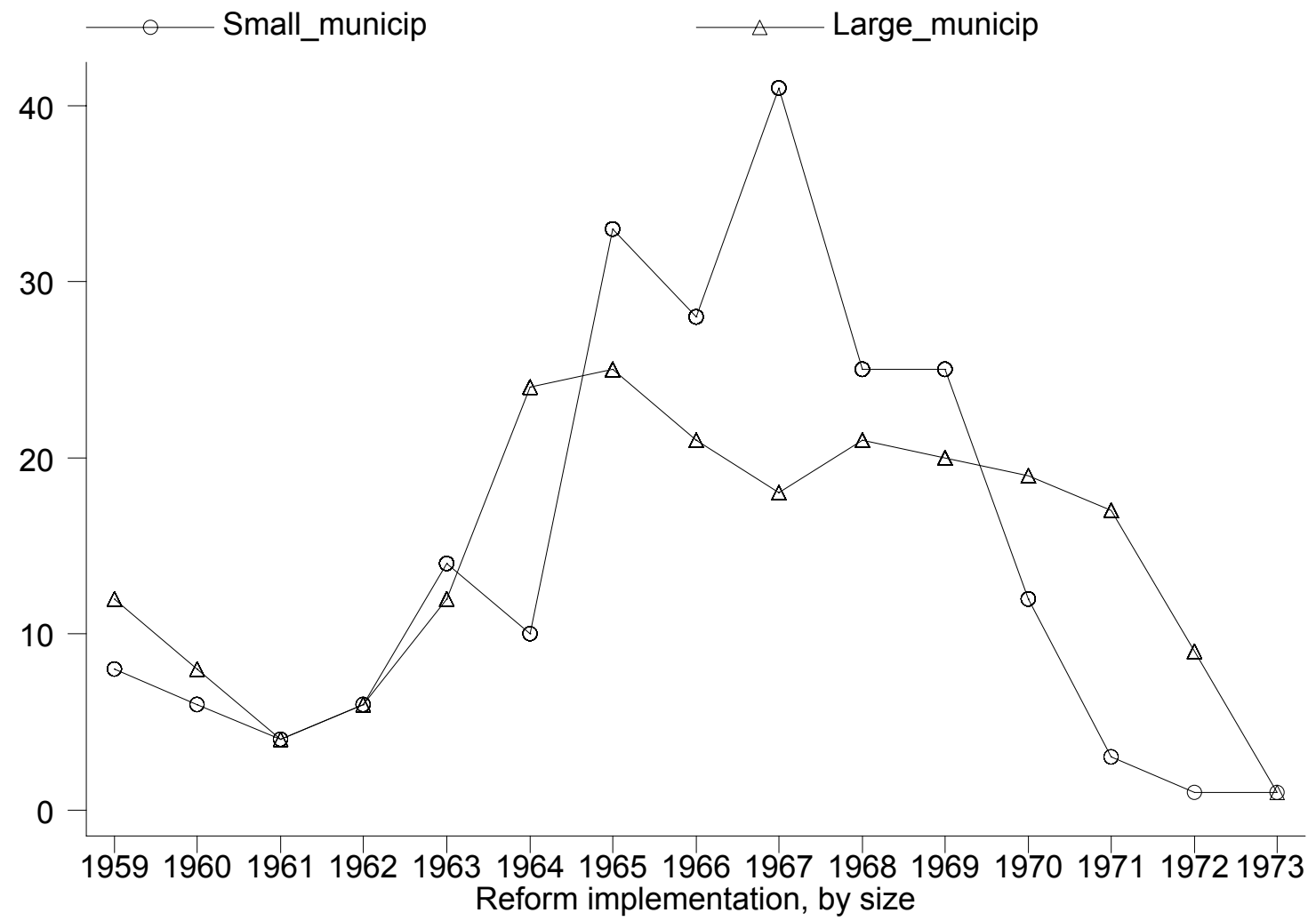

Small (large) municipality is defined as below (above) median municipality as measured by population size in 1960 . 
Appendix Table 1:

Timing of the Implementation of the Reform

Dependent Variable: Year of Reform

\begin{tabular}{|c|c|c|}
\hline & Coefficient & Standard error \\
\hline County2 & -1.95 & .65 \\
\hline County3 & 5.02 & 5.23 \\
\hline County4 & -.64 & .70 \\
\hline County5 & -.88 & .67 \\
\hline County6 & -.90 & .62 \\
\hline County7 & -1.21 & .63 \\
\hline County 8 & -1.90 & .64 \\
\hline County 9 & -1.21 & .64 \\
\hline County 10 & -2.20 & .71 \\
\hline County 11 & -.54 & .63 \\
\hline County 12 & -1.4 & .60 \\
\hline County 13 & -.45 & .70 \\
\hline County 14 & 1.23 & .59 \\
\hline County 15 & -1.54 & .58 \\
\hline County 16 & .04 & .60 \\
\hline County 17 & -1.21 & .57 \\
\hline County 18 & -.26 & .65 \\
\hline County 19 & -2.77 & .71 \\
\hline $\begin{array}{l}\text { Share of Fathers with Some } \\
\text { College }\end{array}$ & .92 & 3.88 \\
\hline $\begin{array}{l}\text { Share of Mothers with Some } \\
\text { College }\end{array}$ & 12.30 & 8.31 \\
\hline Father's Income (mean) & -.007 & .004 \\
\hline Mother's Income (mean) & -.01 & .01 \\
\hline Father's Age (mean) & .11 & .16 \\
\hline Mother's Age (mean) & -.12 & .19 \\
\hline Size of Municipality/100 & -.03 & .03 \\
\hline Unemployment Rate 1960 & -6.22 & 11.63 \\
\hline $\begin{array}{l}\text { Share Workers in Manufacturing } \\
1960\end{array}$ & 1.15 & 3.05 \\
\hline $\begin{array}{l}\text { Share Workers in Private Services } \\
1960\end{array}$ & 5.95 & 6.23 \\
\hline Share Labour Vote 1961 & 2.34 & 2.19 \\
\hline Constant term & 1969.14 & 6.95 \\
\hline
\end{tabular}

Robust standard errors. All variables are municipality level variables. 